\title{
The upcoming rise of SMEs in cross-border public procurement: is it a matter of networking capabilities?
}

\author{
Teresa Fayos $^{1}$ (D) Haydeé Calderón ${ }^{1}$ (D) Juan Manuel García-García ${ }^{2}$ (D) \\ Belén Derqui ${ }^{3}$ (D)
}

Accepted: 7 February 2022 / Published online: 7 March 2022

(C) The Author(s) 2022

\begin{abstract}
The participation of SMEs in public procurement is a recurring theme in recent academic literature. However, little attention has been paid to its influence in cross-border procurement. To participate in this market, SMEs must overcome barriers that make the task difficult and minimise their chances of winning contracts. Within this context, dynamic capabilities in general, and networking ones in particular, are crucial to overcome barriers and boost performance. This article presents an abductive qualitative research study of multiple cases using CAQDAS to analyse which networking capabilities prepare SMEs for cross-border public procurement processes. The results show not only how these capabilities have enabled SMEs to perform well in this environment but also which barriers have helped them to overcome each phase of the procurement process. The article also provides recommendations for both SMEs that decide to enter this market and the administrations that wish to support them.
\end{abstract}

Keywords Dynamic networking capabilities - Cross-border public procurement SMEs · Barriers

\section{Resumen}

La participación de las SME en licitaciones públicas es un tema recurrente en la literatura académica reciente, sin embargo, se ha prestado poca atención a la participación de las PYME en licitaciones internacionales o transfronterizas. Las SME que quieren participar en una licitación pública internacional debe superar barreras internas y externas que dificultan la tarea y minimizan las posibilidades de que le sea concedida la licitación. En este contexto, las capacidades dinámicas son fundamentales para que las PYME puedan enfrentarse y resolver dichas barreras en el contexto

Teresa Fayos

Teresa.fayos@uv.es

1 Universidad de Valencia, Av. Tarongers S/N, 46022 Valencia, Spain

2 Faculty of Economics, Polytechnic University of Valencia, Valencia, Spain

3 IQS School of Management, Universitat Ramon Llull, Barcelona, Spain 
internacional. Especialmente son las capacidades de establecer redes las que pueden hacer que las PYME aumenten su desempeño en el ámbito de las licitaciones internacionales. Este artículo presenta una investigación cualitativa de casos múltiples, de corte abductivo apoyada por un CAQDAS, que aborda en que medida las capacidades de establecer redes preparan a la PYME a enfrentarse y tener éxito en los procesos de licitación pública internacional. Los resultados muestran no sólo como estas capacidades han facilitado a las PYME desempeñarse bien en este complejo entorno, sino también qué barreras han contribuido a superar en cada fase de la licitación internacional. También aporta recomendaciones tanto para las PYME que decidan entrar en este mercado como para las administraciones públicas que deseen apoyarlas.

Palabras clave Capacidades dinámicas de networking · Licitaciones públicas internacionales $\cdot \mathrm{PYME} \cdot$ barreras

\section{Summary highlights}

Contributions: This paper contributes to the literature by opening a new line integrating two research areas: the problems facing SMEs in cross-border public procurement processes and dynamic networking capabilities.

Research questions/purpose: To understand how dynamic networking capabilities help SMEs to overcome the barriers they encounter in the different phases of international public tenders.

Basic methods and information/data: Qualitative research supported by a CAQDAS based on in-depth interviews with SMEs with experience in international public tenders.

Results/findings: Twenty-one (21) barriers were identified, of which 14 can be overcome thanks to dynamic networking capabilities.

Limitations: Due to its qualitative nature, the study is exploratory and the data were collected from firms from a single EU country.

Theoretical implications and recommendations for future research: SMEs consider that each international public tender presents very different challenges, hence the need for more theory-based studies.

Practical implications for management and recommendations: A list of the dynamic networking capabilities that SMEs must develop to overcome each barrier in each phase of a cross-border international procurement is provided.

Policy implications and recommendations: Policies should be implemented by public administrations to support the development of dynamic networking capabilities between SMEs and all stakeholders involved in the international tender 
market; among these policies, the development of Public Procurement 4.0 is urgently required.

Suggestions for future research avenues: We propose a longitudinal quantitative research at EU level encompassing sectors, countries, and bidding and financing bodies on the essential dynamic capabilities to be developed by SMEs.

\section{Introduction}

From the perspective of SMEs, the cross-border public procurement (CBPP) market is complex and largely unknown. However, it represents an interesting alternative for approaching international expansion. The role of SMEs in the EU has traditionally been crucial for economic growth (Albano et al 2015). Despite the lack of specific integrated statistics on the worldwide scope of cross-border procurement for SMEs (Muñoz-García \& Vila, 2019), the size of the public procurement market is around $12 \%$ of the GDP of OECD countries (OECD, 2019), although some authors consider that this percentage likely misrepresents the true size of public procurement (Hafsa et al., 2021). In the EU, the public purchase of goods and services accounts for approximately $16 \%$ of GDP (European Commission, 2017). Despite the fact that 99\% of EU corporations are SMEs, they only obtained one third of the value of public procurement contracts in the EU (de Bas et al., 2020).

SMEs that internationalise through CBPP obtain advantages as this form of entering foreign markets does not require financing the buyer, it has a low risk of non-payment and demand is normally predetermined (Muro, 2012). However, it also poses a specific set of problems. Although there are very rigorous academic studies analysing CBPP (Kutlina-Dimitrova and Lakatos, 2016), over the last 15 years, the topic has gradually begun to attract more interest, and important contributions have been made in identifying the barriers that affect SMEs when it comes to approaching the public procurement market (Loader, 2005; Karjalainen and Kemppainen, 2008; Albano et al., 2015). The reduction of barriers has been studied from the perspective of knowledge management (e.g. Saastamoinen et al., 2018), relational and procedural (e.g. Flynn and Davis, 2017b; Reijonen et al., 2022) and learning (e.g. Calderón et al., 2018) capabilities. However, most studies have not considered its cross-border aspects.

There is also a gap in the literature relating to the performance of SMEs in public contracts in general (Tammi et al., 2016), and although there has been a recent proliferation of very interesting research focusing on SME participation in national or local contracts (e.g. Flynn 2017; 2018; Flynn and Davis, 2016; 2017a, b; Saastamoinen et al., 2017; 2018; Reijonen et al., 2022; Namagembe et al., 2021), research on the participation of SMEs in international public procurement is virtually non-existent.

Cross-border public procurement takes place in a dynamic and complex environment where dynamic capabilities acquire significance. Analysing the literature, it is clear that dynamic capabilities exist in international companies (Frasquet et al., 
2013), as in these environments the effect of their application is more notable (Pehrsson et al., 2015) due to their complexity, dynamism and the entrepreneurial approach that is prevalent in such processes (Frasquet et al., 2018).

As Flynn (2017a, p. 991) confirms, "firm size is positively associated with tendering resources and capabilities. Resources and capabilities, in turn, influence tendering activity and performance", so capabilities are important for winning contracts.

Within the context of cross-border public procurement, literature (e.g. Peck and Cabras, 2010; Mckevitt and Davis, 2013) suggests that one important dynamic capability SMEs must posses are networking capabilities. The central proposition of this paper is that SMEs aspiring to perform well in direct cross-border public procurement and overcome the barriers inherent to it must develop these network dynamic capabilities. Given the gap in the literature in this field and the need to use qualitative research approaches capable of identifying the nuances of the relationships (Flynn and Davis, 2017a; p. 364), this study aimed to understand how dynamic networking capabilities help Spanish SMEs to overcome internal or external barriers in the international public procurement market. With this objective in mind, the following sub-objectives were set: (a) identify networking capabilities developed at each phase of the procurement, and (b) determine the relationship between the developed networking capabilities and the barriers overcome. Spanish SMEs-the scope of this study - are on average smaller than European ones, and in the 2011-2016 period, only 317 SMEs won cross-border contracts. Therefore, analysing this collective within the Spanish context is especially important (Muñoz-García and Vila, 2019).

\section{Literature review}

\section{Cross-border public procurement and SMEs}

Procurement is a formal and competitive procedure through which offers for the acquisition of goods, works or services are requested, received and evaluated and the contract is awarded to the tenderer offering the most advantageous proposal. Procurement can be public or private, and public procurement can be cross-border or local. In cross-border procurement, there are different types of public buyers: national governments and their different levels of administration (regional, local, etc.), non-financial international institutions (Europeaid, EDF, UN, etc.), and financial institutions (WB, IDB, EIB, etc.). Governments are the largest consumers of goods and services, and they represent a significant market opportunity for all businesses given that they are an attractive, reliable and prestigious client (Loader, 2005). Recently some authors (e.g. Loosemore et al., 2021) have called for the incorporation and study of a responsible social approach in the field of public tenders.

Cross-border procurement is an important form of internationalisation for companies (Muñoz-García and Vila, 2019). In some regards, this market has great similarities with traditional export markets, such as the need for enterprises to establish sales strategies (approach to and preparation of bids), accredit references and/ or have prior experience, the importance of local support networks, the need to perform marketing activities and the importance of establishing a policy of partnerships 
(Muro, 2012). Nevertheless, globalisation has not achieved the same efficiency in cross-border public procurement as in the private international commercial sphere (Clear et al., 2020), and Herz and Varela-Irima (2020) quantified that local companies are 900 times more likely to win contracts than foreign firms.

Bearing in mind the specific influence of SMEs within the global economic context of any country, they are under-represented as suppliers in the public sector (McKevitt and Davis 2013; Flynn and Davis 2016). The reasons reported in academic literature are contradictory. Loader (2013) states that SMEs encounter significant barriers and difficulties partly due to the complexity of the processes; Kutlina-Dimitrova and Lakatos (2016) state that in international procurement, the propensity to contract foreign companies will be greater, among other factors, in contracts valued at more than one million euros, which is detrimental to SMEs. However, Glas and Ebig (2018) have claimed that SMEs do not win more contracts the smaller the size of the tender.. Instead, other factors influence SME success, such as the type of public procurement procedure, the number of participating companies and the overall tender volume. For Spanish SMEs, Muñoz-García and Vila (2019) have shown that there is a "crossborder size bias conjecture" whereby the proportion of SMEs that win direct crossborder contracts is smaller than those that win domestic tenders.

However, despite the drawbacks SME face from the outset, Flynn and Davis (2017b) state that SMEs can be "genuine contenders for public contracts provided they are given the opportunity to compete", and although administrations will consider the best price-quality ratio to select and choose the best bid, at present, public procurement processes are sometimes a strategic instrument for administrations pursuing additional objectives (Schapper et al., 2006), e.g. to support SMEs (OECD, 2019; Loader, 2018).

It seems clear, given the differences between SMEs and large companies, that the size parameter is crucial to finding and resolving potential barriers that may exist in public procurement. Calderón et al. (2018) synthesised the results of the most relevant studies into the barriers for accessing the international public procurement market, distinguishing between internal barriers (deriving from the characteristics and activity of the company) and external barriers (those caused by the environment), and within each type differentiating according to the source of the barrier. At a third level, the barriers were sub-categorised in accordance with Karjalainen and Kemppainen (2008), who differentiated according to the source of the problem. Based on our review of the literature, a constant factor seems to be that many of the obstacles reported by companies when approaching the public procurement market stem from the sphere of the administration and, to a large extent, from the procurement systems and procedures. While there is a certain degree of consensus, some authors attach more importance to certain barriers over others depending on the reality of the country, sector or size of the company, and even on the position of the SME in the supply chain (Karjalainen and Kemppainen, 2008; Cabras, 2011; Flynn et al., 2013).

\section{Dynamic capabilities of SMEs in the cross-border procurement market}

Dynamic capabilities are "the inimitable capability to design, redesign, configure and reconfigure the company's asset base in order to respond to changing environments 
and technologies" (Augier and Teece, 2007, p. 179). Dynamic capabilities have been widely used to study internationalisation processes as not only is the international environment unstable by nature (Pehrsson et al., 2015), when a company operates in many markets with different cultures and institutions it is necessary to assimilate knowledge and incorporate it into the strategy and operations of that company (Pitelis and Teece, 2010), and the more diverse and higher the level of change in the business environment, the more critical these capabilities become (Augier and Teece, 2007). Moreover, Fang and Zou (2009) showed that the more dynamic the environment, the more pronounced the effect of dynamic capabilities on performance. Therefore, we believe that dynamic capabilities may be relevant in the study of international procurement, not only because this market occupies an international sphere that is different to local contexts and unstable by nature but also because each procurement process takes place in a different market to the one the company is accustomed to operating in.

With regard to the types of dynamic capabilities in internationalisation process, literature describes a variety of capabilities, most notably networking capability (Luo, 2002; Knight and Cavusgil, 2004; Weerawardena et al., 2007; Morgan et al., 2018). Given the characteristics and barriers that SMEs face, and as Flynn and Davis (2017a, p.337) state, "relational capabilities are significant in accounting for success rates in contract competitions and commercial orientation towards the public sector". Therefore, networking capabilities seem to be especially significant in crossborder procurement procedures.

\section{Networking capabilities of SMEs in the cross-border procurement market}

Mitrega et al., (2012, p.739) define networking capability as "the complex organizational capability oriented towards managing business relationships along all their main development stages". Networking capability is especially important for SMEs due to the lack of resources and knowledge necessary to operate in international markets (Gilmore et al., 2006; Pinho and Prange, 2016), by reducing risk, creating value and enabling the development of complementary resources (Nerkar and Paruchuri, 2005; Selnes and Sallis, 2003; Weerawardena et al., 2007) thanks to the availability and skill of management to establish relationships that enable them to access existing knowledge, both outside and within the company, in order to achieve strategic objectives (Nieves, 2014). According to Blyler and Coff (2003), networking not only enables the transmission of complex knowledge, it also creates new resources. Additionally, network ties have a significant influence on firms' internationalisation (Blyler and Coff, 2003; Ciravegna et al., 2014; Ellis and Pecotich, 2001; Ellis, 2011; Fernhaber and Li, 2013) as they provide paths to entry into international markets, help screen and evaluate potential partners, and reduce exchange risks through the creation of mutual trust (Larson, 1992). Therefore, building and maintaining relevant, superior and effective networks is an integral part of a successful internationalisation process (Liesch et al., 2002).

From the perspective of cross-border procurement, Peck and Cabras (2010) outlined an existing trend among SMEs to participate in procurement processes and more formal and complex contracts, operating through networking as a need to tackle certain types of barriers that arise in this process. This model of participation 
allows them to gather resources and capabilities with a partner that acts as a leader and resolves the problems arising from the low level of experience of the other companies (McKevitt and Davis, 2013).

Different reasons justify the need for SMEs to develop networking capabilities, as argued by Muro (2012) who claim that building partnerships to submit joint procurement bids allows such enterprises to gain a partner and avoid a competitor, while Gilmore (2011) claims that it is necessary to obtain useful business information. Operators without prior experience in other contracts should create consortia, or bodies, preferably of different nationalities, and if possible they should include local operators (McKevitt and Davis 2013), since local bidders are more likely to be successful than foreign ones (Clear et al., 2020; Herz and Varela-Irimia, 2020). Given that establishing agreements between companies is not without difficulties (Quayle, 2002; Morrissey and Pittaway, 2004), public administrations created "SME-friendly" policies, which are actions designed to encourage companies to participate as part of a consortium (Flynn and Davis, 2016).

By analysing networking capabilities from a dynamic relationship perspective, following Mitrega et al. (2012) and Mu (2014), we propose grouping these capabilities into three phases (Table 1).

As Loader (2015) indicates, four (4) stages can be distinguished in a procurement process: identification of the procurement process; preparation and presentation; implementation; and the end of the process. Thus, in order to research the networking relationships of SMEs in cross-border procurement procedures, we propose a dynamic approach integrating the phases of the relationship, as well as the phases of the procurement process (Table 2).

\section{Methods}

\section{Research context and design}

Spanish companies participate in cross-border procurement contracts either directly or through consortia with local or third country companies. In 2019, these contracts were valued at 52,225 million euros (Secretaría de Estado de Comercio, 2021). In 2020, Spain, a country where $99.7 \%$ of companies are SMEs (Dirección General

Table 1 Network capability from a dynamic perspective of the relationship

\begin{tabular}{|c|c|c|}
\hline $\begin{array}{l}\text { Phases of the } \\
\text { relationship }\end{array}$ & Mitrega et al. (2012) & Mu (2014) \\
\hline 1 & $\begin{array}{l}\text { Capability to establish the relationship } \\
\text { - Search } \\
\text { - Selection } \\
\text { - Negotiation }\end{array}$ & $\begin{array}{l}\text { Finding network partners } \\
\text { - Identifying and selecting the suitable } \\
\text { partner }\end{array}$ \\
\hline 2 & $\begin{array}{l}\text { Capability during the relationship } \\
\text { - Management of the business relationship } \\
\text { - Management of the personal relationship } \\
\text { - Conflict management }\end{array}$ & $\begin{array}{l}\text { Manage network relationships } \\
\text { Relationship skills in order to efficiently and } \\
\text { effectively manage the relationship } \\
\text { - Establish management mechanisms }\end{array}$ \\
\hline 3 & End of the relationship & \\
\hline
\end{tabular}




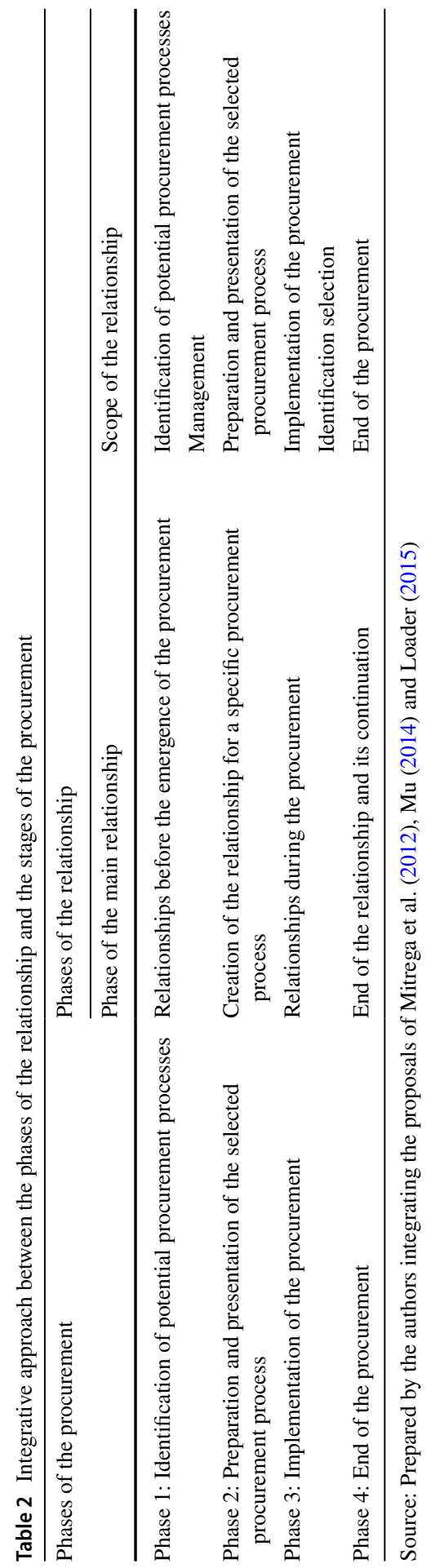


de Industria y de la Pequeña y Mediana Empresas, 2020), ranked as the first nonborrowing country to be awarded the most contracts by the Inter-American Development Bank. Spanish companies have won 1929 international tenders in Latin America, valued at more than 1,943 million euros (LICIRED, 2021).

Given the absence of prior academic studies, we used the qualitative case-based method to identify and analyse the networking capabilities developed by SMEs to handle the problems that CBPPs pose in each phase of procurement. This was the appropriate methodology due to the exploratory nature of our objectives given that, as reported by Pratt (2009), this methodology is flexible and allows unexpected findings to emerge. This method has been shown to be useful when approaching questions such as the how and why (Yin, 2014), both within the field of dynamic capabilities (Eriksson, 2014; Frasquet et al., 2018), in the study of networks in the field of SMEs (Masiello et al., 2013), and in research into cross-border procurement (Calderón et al., 2018). The qualitative research process was adapted to the progressive focusing model proposed by Sinkovics and Alfoldi (2012) which employs an abductive model (Nordquist et al., 2009) combining deduction and induction. This method was used by McGrath et al. (2019) to study networking capabilities as it facilitates the understanding of the complex nature of relationships and networks (Hanna and Walsh, 2008; Jack et al., 2015; Leppäaho et al., 2018). The information collection method used was semi-structured in-depth individual interviews.

Since this research focused on SMEs, instead of adopting a single case study approach in line with Johnsson and Foss (2011), a multiple firm approach was adopted following Yin (2014) and Leppäaho et al., (2018). For the selection of the number of companies, the recommendation of Eisenhardt (1989) was considered, which establishes a number of between four and ten cases to be analysed in qualitative multiple case analysis. We applied the principle of purposeful rather than random sampling following Patton (2002). Thus, in order to be considered in the study, the companies had to satisfy the requirements of being SMEs, and having bid for and having won direct cross-border procurement contracts. Additionally, the representativeness and chance to learn from the case was taken into consideration, together with accessibility to the company. In order to identify companies, their websites and existing reports, and other secondary information were analysed in order to overcome the limitation of the qualitative method by obtaining different points of view on the same phenomenon (Eisenhardt and Graebner, 2007) and enabling the triangulation of information. Access was gained to six companies that met the requirements, and a public promotion entity was also included, given its relevance in this field, as not only had it won cross-border contracts in its sphere of activity, it also had a department to help SMEs win cross-border contracts, thus allowing us to obtain cross-sectoral knowledge. The interviewees were management staff responsible for cross-border procurement (Table 3).

\section{Data collection and analysis}

With regard to the method of analysing the content of the information, recurrent or central themes were sought, based on initial codes using the literature, 


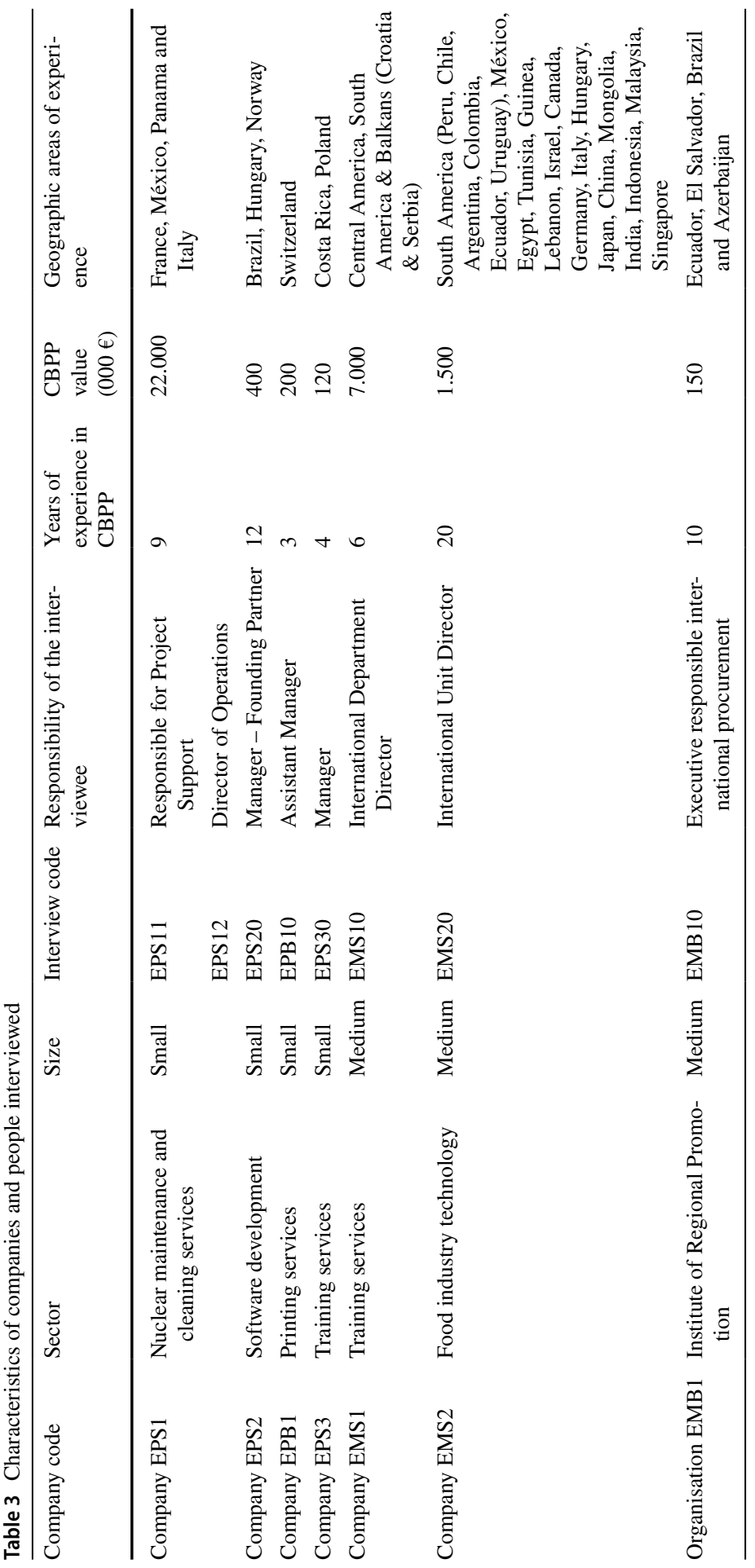


as advised by Patton (2002), initially in each case individually and subsequently with cross-case analysis (Yin, 2003) in order to study differences and similarities. Triangulation was also carried out in the content analysis phase; three researchers participated in the process of coding the content of the interviews, as suggested by Huberman et al (2014) in an inductivedeductiveinductive circular process, first individually and then collectively, for the discussion of new topics and codes absent from prior literature. Following the model proposed in the literature review, 18 barriers were identified and coded (9 internal and 9 external). However, from the analysis of the content of the interviews, three new specific barriers were identified (two external and one internal) that had not been specifically and previously contrasted in the literature. New codes were therefore assigned to these barriers (BEFTP, BERPS and BIFEP). The 21 barriers are shown in Table 4 together with the percentage of times out of the total in which they were mentioned by the companies.

The thematic analysis sequence followed is outlined in Fig. 1. Decisive findings were summarised in tables and figures following Eisenhardt and Graebner (2007), and the authors quoted directly from the interviews to illustrate certain findings.

Table 4 Frequency of barriers referenced in the interviews carried out

\begin{tabular}{|c|c|c|}
\hline Code & Description of the barrier & $\begin{array}{l}\% \text { on total } \\
\text { references }\end{array}$ \\
\hline BECRQ & Compliance requirements & $15 \%$ \\
\hline BENOR & $\begin{array}{l}\text { Compliance with administrative and regulatory standards in the interna- } \\
\text { tional market of destination }\end{array}$ & $8 \%$ \\
\hline BECPR & Procedural complexity & $7 \%$ \\
\hline BEFEX & $\begin{array}{l}\text { The need to demonstrate experience and a prior track record (risk aversion } \\
\text { by the administration) }\end{array}$ & $7 \%$ \\
\hline BIERA & Scarcity of administrative and management resources & $7 \%$ \\
\hline BIFHI & Lack of language skills within companies & $7 \%$ \\
\hline BIERF & Shortage of financial resources & $6 \%$ \\
\hline BIFIL & Lack of information about tender announcements & $6 \%$ \\
\hline BIFHG & Lack of management skills & $6 \%$ \\
\hline BIFIM & Lack of market knowledge & $5 \%$ \\
\hline BEFTP & Short deadlines for bid preparation & $5 \%$ \\
\hline BERPS & Political and Security Risks in the international market of destination & $4 \%$ \\
\hline BIFCR & Lack of knowledge about the usual compliance requirements & $3 \%$ \\
\hline BITCS & Size of contracts and delivery capability & $3 \%$ \\
\hline BEFCA & Lack of communication between management and provider & $2 \%$ \\
\hline BEFRP & Lack of final, expected return on contracts & $2 \%$ \\
\hline BIFRL & Lack of legal resources & $2 \%$ \\
\hline BECUL & Cultural differences with international partners & $2 \%$ \\
\hline BEERA & Excessive delays in administration & $2 \%$ \\
\hline BEFCM & Currency fluctuations (exchange) & $2 \%$ \\
\hline BIFEP & Lack of experience among staff in international travel & $1 \%$ \\
\hline
\end{tabular}


Fig. 1 Thematic analysis sequence followed

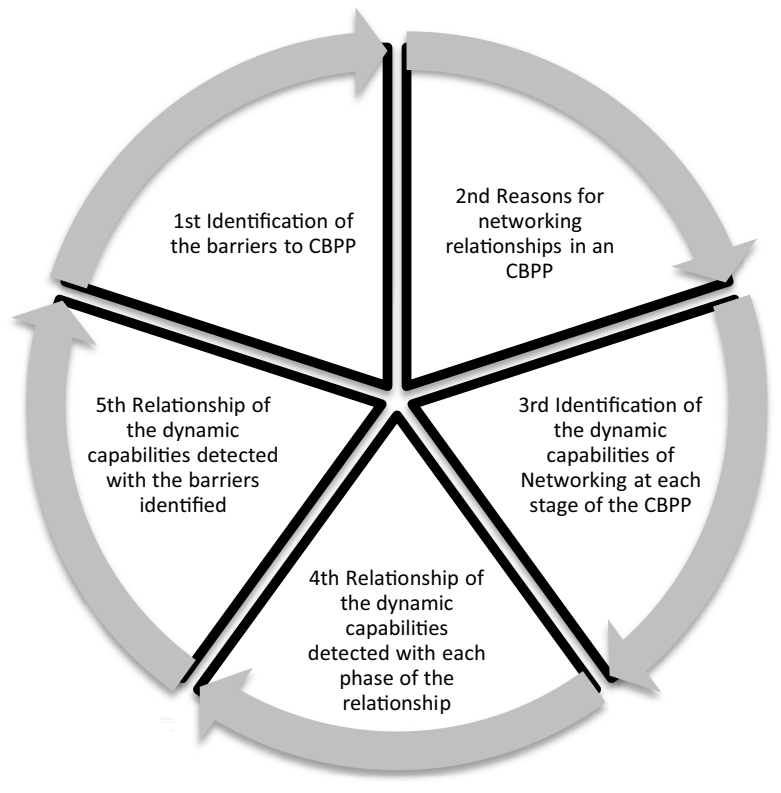

\section{Findings}

\section{Barriers identified}

Table 4 shows the barriers that the SMEs interviewed had faced in their procurement processes. Additionally, we identified these barriers as internal (IB) or external (EB), and also incorporated the percentage of quotations over the total number into the table.

It is interesting to observe that, of the five barriers mentioned most by the companies interviewed, four were external barriers: compliance with requirements (BECRQ), compliance with administrative and regulatory standards in the international market of destination (BENOR), the complexity of the procedures (BECPR) and the need to demonstrate experience and a prior track record (risk aversion on the part of the administration) (BEFEX). The most noteworthy internal barriers were the lack of resources, both administrative and managerial (BIERA), as well as financial (BIERF), along with the lack of skills, information and knowledge.

\section{Networking capabilities developed in each phase of a CBPP}

The main reasons for creating networking relationships in order to gain an international contract are as follows: (a) the obligation or need to team up with local and/or international partners for public procurement bids; (b) the need to have external professionals and specialist technicians that make it possible to complement and enhance the technical level of the bid presented and subsequently the 
implementation of the projects; (c) the need to have guidance and the support of consultants, professionals and public entities in order to detect the procurement process, look for partners, seek information about the markets covered by the procurement, design and submit bids, and obtain economic support for the management of securities and guarantees.

EMS10: "Our consortia were almost always with foreign partners. Why? Because multilateral institutions are usually created to bring together the synergies of entities that come from different countries and with different experiences."

The cross-case analysis did not reveal noteworthy differences in terms of the dynamic networking capabilities highlighted by the different companies-and all of them identified at least five-not even when differentiating between small and medium-sized companies. Therefore, the analysis and discussion of the networking capabilities was carried out by grouping them according to the phase of procurement in which they are required. Thus, in the prior phase (phase 0), "Identification of potential procurement processes", the companies developed the capacity to establish relationships, both in their country of origin and in the destination country, e.g. by meeting and subsequently taking care of and maintaining contact with local officials that visited the country on trade missions, or in the destination country through contacts with the purchasing managers of projects, law firms and different types of contacts with the actual bodies that are expected to provide some kind of procurement process.

In phase 1 of the procurement, "Preparation and presentation of the selected procurement process", establishing relationships includes the development of search, selection and negotiation capabilities, given that this phase will result in an agreement (Mitrega et al., 2012). In the case of cross-border procurement, we identified four different types of networking capabilities. We considered these capabilities to be dynamic as each procurement process takes place not only with a different time but also with a different contractor, country and characteristics.

Firstly, the capability to recognise one's own shortcomings and detail the complementary profile to seek, and consequently the criteria that potential partners need to fulfil, requires deep and critical analysis of the tender specifications, the country in which it will take place, and the company's own capabilities or shortcomings.

EMS20: "Most cross-border contracts require a group or some partners who group together and are able to attain the first - shall we say - milestone, in other words, 'To have a good consortium that covers all the areas of the procurement in the best way possible, with the best chance of success', that is the first challenge."

Other capabilities developed in this phase are those relating to the search for a partner, where to find them (e.g. in congresses, symposia) and how to look for and obtain the right partner. The companies show the capability to select the correct partner from all potential candidates, valuing those that best complement them and suit the requirements of each contract, and subsequently convince them to participate. 
The second phase is the "implementation of the procurement", the phase in which business management, personal relationship building and conflict management capabilities are considered (Duarte and Davies, 2003). Business management and personal relationship building capabilities are closely linked to the integration of the resources of the different participants, so sometimes protocols are developed which are considered a source of innovation in the improvement of relationships:

EPS30: "When it comes to also integrating those external protocols into the internal working protocols of the company (...) we have had to be agile and flexible in terms of incorporating these new procedures, and have subsequently incorporated each of them because they have been useful."

The interviewed companies develop conflict management capabilities, both with the tenderer and among the partners with whom they submitted the bid.

EPS12: "I can give you the example of an important partner that has quality and purchase procedures that are exactly the same for building a nuclear power station as they are for purchasing a screw in a hardware store. We are much more flexible, more reactive and that creates problems, which on the other hand is also good, because they take care of the entire administrative report part, so we could say that they are balanced."

Lastly, the fact that the project is implemented in a different country with foreign rules and legislation implies that it requires procurement management capabilities in the destination, for which purpose local relationships must be established. We also consider these capabilities to be dynamic as the company gradually adjusts and adapts to both the development of the relationship and the changing national, local and international environment in which it is carried out.

EPS11: "And all of that is quite difficult, because every country functions dif-

ferently. How do we resolve these issues? We use consultancies which advise us on how to do it".

As regards the last phase (phase 3-“end of the procurement"), given that the end takes place because there is a pre-established deadline and not due to other factors related to the relationship, it was not considered relevant to examine the networking relationships in greater depth, although the companies may have been interested in maintaining contact for future projects.

By way of a summary, Table 5 outlines the networking capabilities identified considering both the dynamics of the relationship over time as proposed by Mitrega et al. (2012) and the procurement phases proposed by Loader (2015).

\section{Relationship between networking capabilities and barriers identified}

Having reviewed the networking capabilities developed by the companies interviewed, we will now analyse how they enable the companies to overcome the different external and internal barriers in the CBPP market. Figure 2, created based on the concurrency testing carried out with ATLAS.Ti 8 software, shows that the 


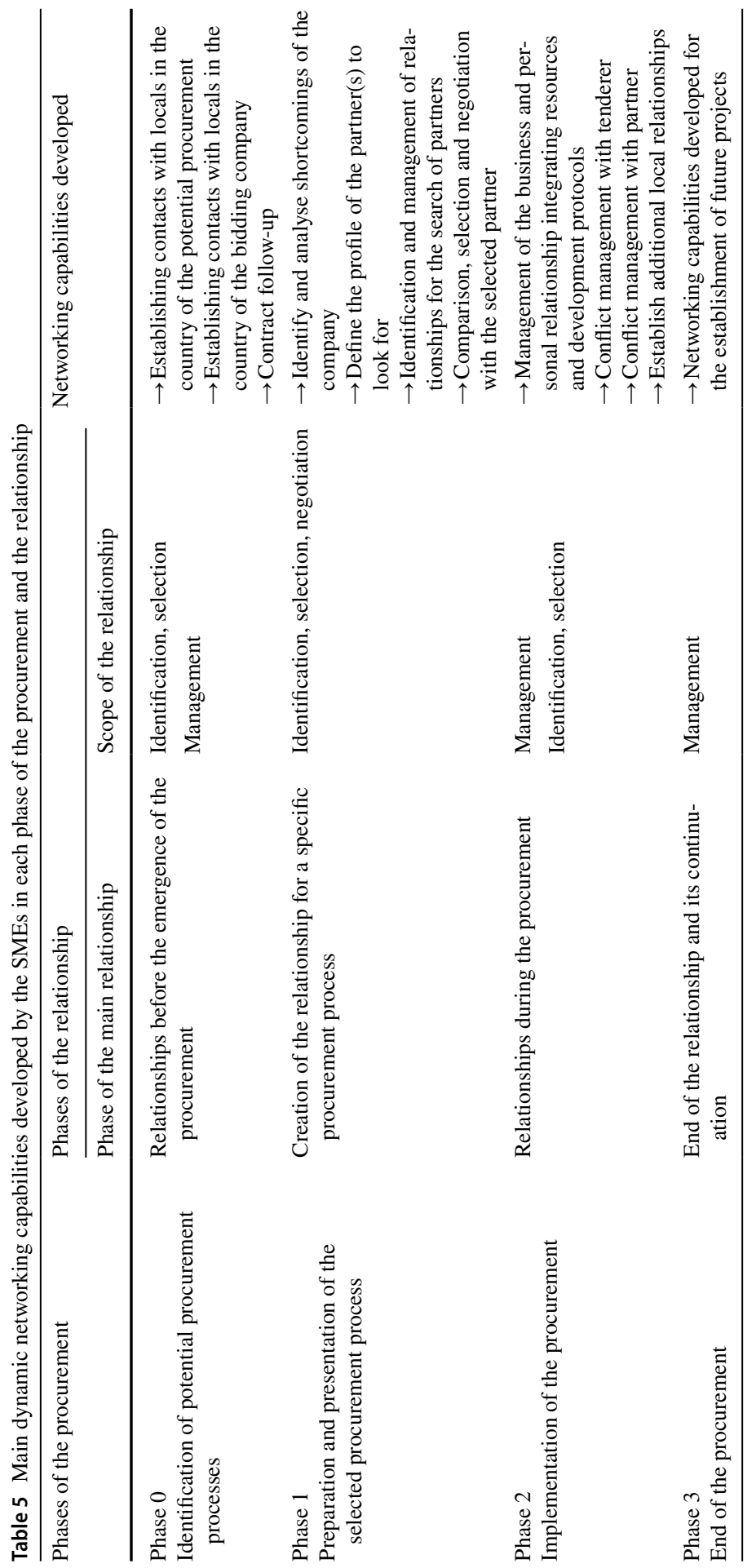




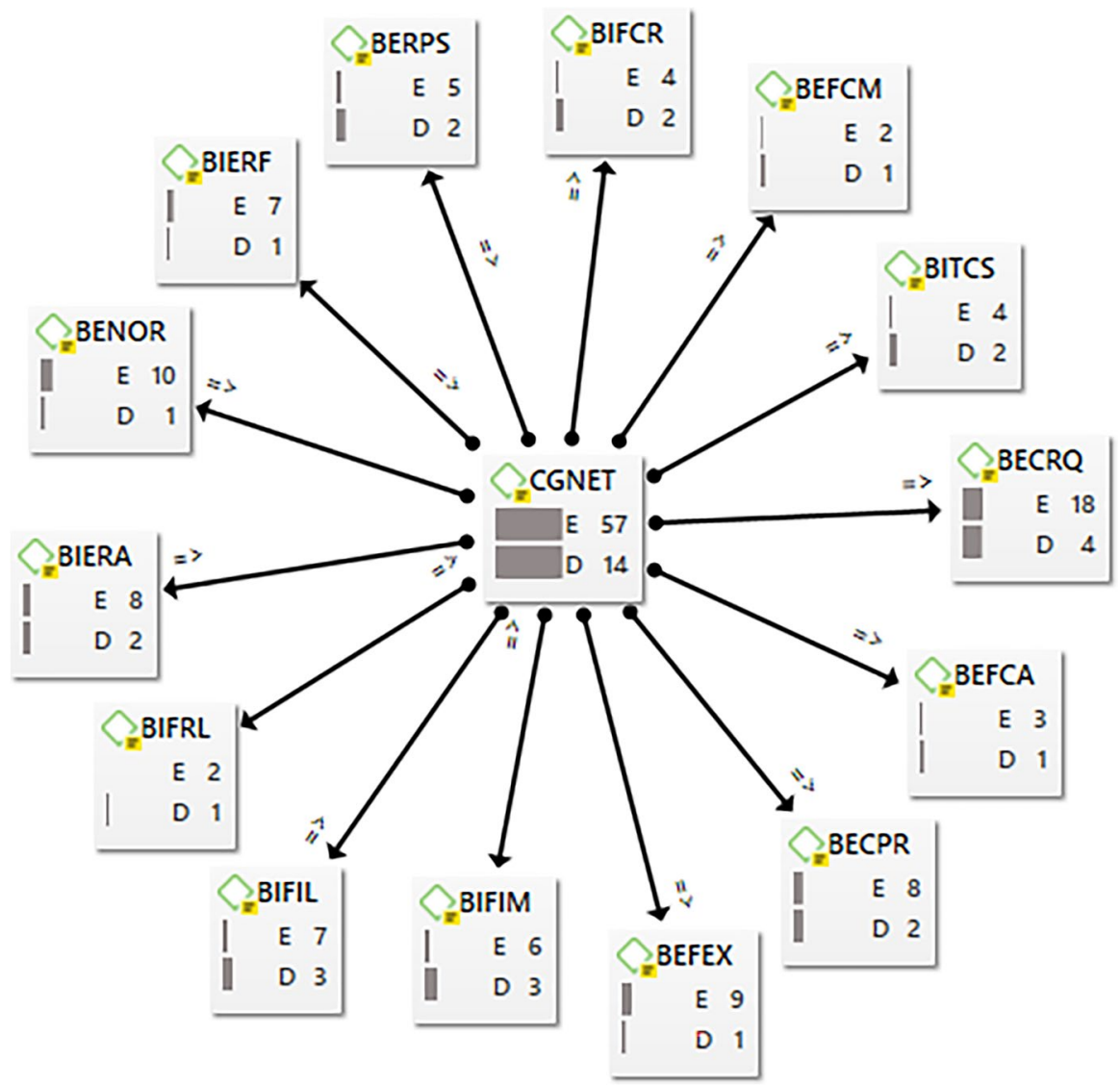

Fig. 2 Barriers overcome thanks to dynamic networking capabilities. Within the tables that appear in the figure, two values are observed $\{\mathrm{E}-\mathrm{D}\}, \mathrm{E}$ (Enumeration) indicates the total number of times firms refer to the barrier/dynamic networking capabilities during the interviews. D (Density) indicates the total number of links identified between the codes corresponding to the barriers and the dynamic networking capabilities

creation of close partnerships with partners, consultancies, advisory bodies and local or international public institutions allow the companies to overcome a significant number of external and internal barriers. Specifically, networking capabilities enable these firms to break down 14 of the 21 barriers identified.

Additionally, Table 6 outlines the barrier-networking capabilities concurrent in each phase of the CBPP process. These capabilities are analysed below.

The barrier that contributes most to overcoming dynamic networking capabilities is the one relating to the fulfilment of requirements (BECRQ). By developing dynamic networking capabilities, companies manage to fulfil the requirements (geographic experience, reputation, technical and financial solvency, etc.) imposed in international procurement processes. The partners with which the 


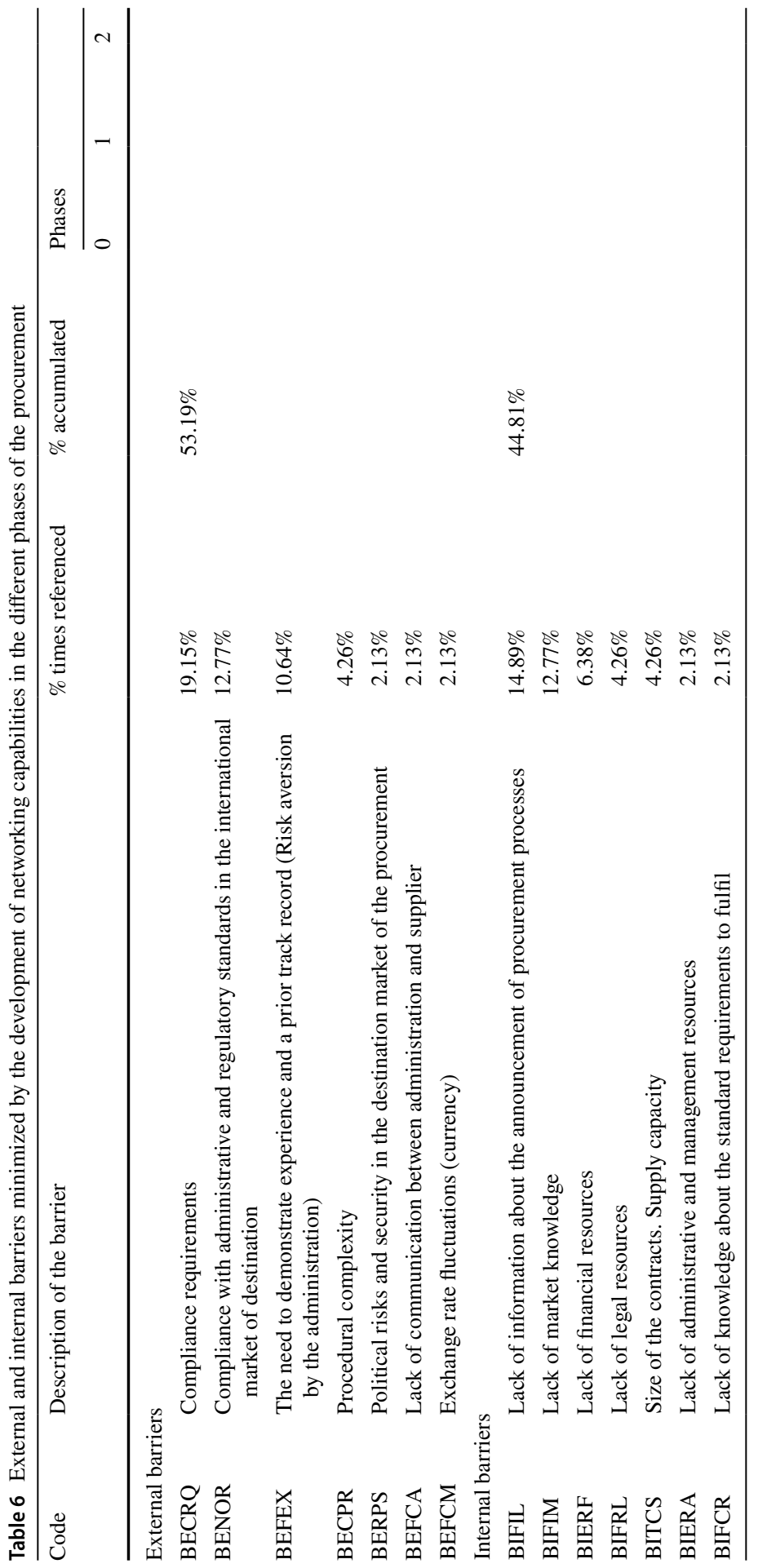


companies participate in procurement processes allow them to complement their capabilities and thus present bids that comply with the minimum requirements:

EMS20: "I have a good consortium that covers all the areas of the procurement process in the best way possible, with the best chance of success", that is the first challenge (...) imagine there are three components, for example, and we know how to do two, but there is one that we are unable to do; if we are unable to find the company that knows how to do the third part, we do not participate.

Compliance with administrative and regulatory standards in the international market of destination (BENOR) is another barrier that can be eliminated through the development of dynamic networking capabilities. The bodies that support internationalisation by providing guidance and training to SMEs are especially relevant in this regard:

EMB10: "There is a part of knowledge of procedures and internal organization, that is to say, there is an administrative part that the companies that have bid a lot here do indeed master but the companies that have to apply this to other countries, and other types of legislations have a lot of difficulties. That is why we are there to offer training for that."

A link may be established between the barrier relating to the often referenced need to demonstrate experience and a prior track record (BEFEX) on the one hand, and dynamic networking capabilities on the other, as one way in which companies comply with the requirement of certifying prior experience in relation to the purpose of the procurement is by submitting joint bids with other companies that do possess this experience:

EPS11: “... The counterpart, the complementary entity, that is to say, when a procurement process requires you to have experience in 3 areas and you just have one, you seek a partner that has the other two or another two partners who each have one."

Procedural complexity (BECPR) is another barrier that dynamic networking capabilities help to overcome. The relationship with larger companies, local partners and consultants helps companies to understand and overcome the complexity of procurement procedures and the entire implicit administrative burden.

Companies develop and manage new relationships with partners, contacts, consultants and even support bodies in the origin and destination countries in order to obtain relevant information in good time about the procurement opportunities that may arise, thus overcoming the main internal barrier identified regarding the lack of information on cross-border procurement (BIFIL).

The same applies with the lack of global knowledge of the market barrier (BIFIM). The relationship with partners and bodies helps enterprises to find out about the market where the company plans to carry out the procurement, enabling it to reduce uncertainty, and boosting its chances of making better bids and thus obtaining better results: 
EMB10: “(...) ultimately, if you don't have knowledge of this market, the ideal thing is to be part of a consortium"

In general, the lack of legal resources (BIFRL) is one of the most common barriers faced by SMEs, and in the CBPP market. It is more efficient for companies to have external collaborators in the destination country than maintain internal legal structures:

EPS11: “...each country has a different legislation... It is quite difficult, but it resolved externally, always locally.”

The size of contracts (BITCS) is another barrier that can be resolved through collaboration with partners. The way to approach a CBPP that is larger than what the company is qualified for is by forming a partnership or consortium with one or more companies.

EPS30: "Due to the limitation of resources and the issue of securities, (...) we cannot go for very large projects, we always have to group together with more people."

Other barriers overcome via networking capabilities that have been reported, albeit less frequently, are those relating to the lack of administrative and management resources (BIERA), and the lack of knowledge about the standard requirements to fulfil (BIFCR).

By way of summary, and complementing the prior analysis, Table 7 proposes the networking capabilities to be developed by SMEs in each procurement phase to overcome each barrier identified in this market.

\section{Discussion and conclusions}

While existing literature is clear on the existence of barriers for SMEs in the procurement market, the academics challenged us to go further. For this reason, we adopted a more specific scope in our research by focusing on direct cross-border public procurement and also approached this topic from the perspective of dynamic networking capabilities. Thus, we integrated two areas in an exploratory way, opening up a new line of research. We added a structure in phases to the study, identifying the dynamic networking capabilities to be developed in each phase of the procurement process and relationship in order to overcome each barrier, and also formally incorporated the study of a new phase prior to the proposals of the scholars who have written about networking.

In response to the question posed in the title of this paper, the results of our study suggest that in the case of Spanish SMEs, their upcoming rise in cross-border public procurement is indeed largely a matter of networking capabilities. Furthermore, the research carried out clearly reveals that dynamic networking capabilities were frequently and clearly referenced by all the companies interviewed, offering ample evidence of their existence and how they have enabled companies to achieve success in the cross-border public procurement market. In other words, not only have we 
Table 7 Networking capabilities to be building by SMEs in cross-border international procurement

\begin{tabular}{|c|c|c|}
\hline $\begin{array}{l}\text { Type of } \\
\text { barrier }\end{array}$ & Code & Description of the barrier \\
\hline \multirow[t]{7}{*}{ Internal } & BIFIL & $\begin{array}{l}\text { Lack of information about } \\
\text { the announcement of } \\
\text { procurement processes }\end{array}$ \\
\hline & BIFIM & Lack of market knowledge \\
\hline & BIERF & Lack of financial resources \\
\hline & BIFRL & Lack of legal resources \\
\hline & BITCS & $\begin{array}{l}\text { Size of the contracts. Supply } \\
\text { capacity }\end{array}$ \\
\hline & BIERA & $\begin{array}{l}\text { Lack of administrative and } \\
\text { management resources }\end{array}$ \\
\hline & BIFCR & $\begin{array}{l}\text { Lack of knowledge about } \\
\text { the standard requirements } \\
\text { to fulfil }\end{array}$ \\
\hline
\end{tabular}

External BECRQ Compliance requirements Bid Networking capabilities developed by the bidding companies
phase

0

Establishing contacts with locals in the country of the potential procurement Establishing contacts with locals in the country of the bidding company Follow-up of contacts

Identify and analyse shortcomings of the company

Define the profile of the partner(s) to look for

Define the criteria that possible partners need to fulfil

Identification and management of relationships for the search of partners

Selection of the person that will look for/select the partner

Comparison, selection and negotiation with the selected partner

Identify and analyse shortcomings of the company

Define the profile of the partner(s) to look for

Define the criteria that possible partners need to fulfil

Identification and management of relationships for the search of partners

Selection of the person that will look for/select the partner

Comparison, selection and negotiation with the selected partner

BENOR Compliance with administra- 2 tive and regulatory standards in the international market of destination

BEFEX The need to demonstrate experience and a prior track record (risk aversion by the administration)

BECPR Procedural complexity

BERPS Political risks and security in 2 the destination market of the procurement

BEFCA Lack of communication between administration and supplier

BEFCM Exchange rate fluctuations (currency)
Management of the business and personal relationship integrating resources and development protocols

Conflict management with tenderer

Conflict management with partner

Establish additional local relationships

$1 \quad$ Identify and analyse shortcomings of the company

Define the profile of the partner(s) to look for

Define the criteria that possible partners need to fulfil

Identification and management of relationships for the search of partners

Selection of the person that will look for/select the partner

Comparison, selection and negotiation with the selected partner

1 and Identify and analyse shortcomings of the company

2 Define the profile of the partner(s) to look for

Define the criteria that possible partners need to fulfil

Identification and management of relationships for the search of partners

Selection of the person that will look for/select the partner

Comparison, selection and negotiation with the selected partner

Management of the business and personal relationship integrating resources and development protocols

Conflict management with tenderer

Conflict management with partner

Establish additional local relationships

2 Management of the business and personal relationship integrating resources and development protocols

Conflict management with tenderer

Conflict management with partner

Establish additional local relationships

0,1 Establishing contacts with locals in the country of the potential procurement

and Establishing contacts with locals in the country of the bidding company

$2 \quad$ Follow up of contacts

Identify and analyse shortcomings of the company

Define the profile of the partner(s) to look for

Define the criteria that possible partners need to fulfil

Identification and management of relationships for the search of partners

Selection of the person that will look for/select the partner

Comparison, selection and negotiation with the selected partner

Management of the business and personal relationship integrating resources and development protocols

Conflict management with tenderer

Conflict management with partner

Establish additional local relationships

1 and Establishing contacts with locals in the country of the bidding company

2 Management of the business and personal relationship integrating resources and development protocols

Establish additional local relationships 
outlined how the SMEs develop the capability to network, we have also shown how the development of networking capabilities has enabled them to acquire/integrate resources and capabilities that have subsequently allowed them to win and properly implement the procurement contract. Our results also suggest that the phase in which companies need to overcome most barriers, which can be achieved through the development of networking capabilities, is the preparation and presentation of the procurement bid; this result may support the theory proposed by Flynn and Davis (2017b), namely that relationship capabilities may make it easier for companies to be selective, only bidding for tenders they can win. Moreover, networking with a company in the contracting country would reduce the expectation of "home bias" to contract locally (Herz and Varela-Irimia, 2020).

Our results also suggest that there are at least two important barriers specific to the direct cross-border market that can be easily overcome through networking capabilities; one is external, compliance with standards in the destination market (BENOR); and the other internal, the lack of knowledge about the destination market (BIFIM). In line with Fang and Zou (2009), we consider these capabilities to be dynamic because each procurement process is implemented in a market different to the local one and normally unstable by nature; in this regard, the recommendations of Felin and Powell (2016), targeted at building dynamic capabilities in dynamic environments, may be a starting point.

This study, in addition to its academic contributions, also have potential implications at managerial level. In particular, in the field of networking new abilities and new challenges emerge for SMEs. One example is the digitalisation of the unstoppable BICE (2018) procurement process, and the unpredictable impact of new and disruptive models that pose real challenges for the administration, bodies and companies, but which also increase the transparency of processes (Obwegeser and Muller, 2018). So-called Public Procurement 4.0 is based on rethinking all existing procurement procedures, and according to the World Bank (2016), economies from all regions are implementing reforms in this regard, yielding multiple benefits (Chibani et al., 2018), not just savings and quicker and simpler processes but also, as indicated by Saastamoinen et al. (2018) and Stritch et al. (2018), new business opportunities by improving SMEs' ability to access cross-border public procurement markets. In this regard, Loader (2015) shows that the "lack of information about the announcement of procurement processes" barrier may be diminishing, although there are major differences between countries as while some do not even have a portal or platform, others already have sophisticated platforms offering a large number of services (World Bank, 2016). Platforms have recently been proposed in this area (e.g. Balance Score Card by Clear et al., 2020; TheBuyForYou by Soylu et al., 2022) despite their still limited scope. At European level, although most EU countries have updated their e-procurement systems, they do not perform systematic assessments of their performance (Magina, 2020).

Another obvious yet equally important general implication deriving from our research is that success in the cross-border public procurement market is not a coincidence. Thus, companies that perform well in the market need to gear themselves towards an international marketing approach, by carrying out prior in-depth internal analyses of their resources, capabilities and the identified environment, 
by studying and networking with tendering bodies, with entities that can provide support in the process, and above all with potential partners in the origin and destination country, but also in other countries if they do not find the right counterpart. Then, they need to design and commit to a medium-term strategy with allocated resources, and carry out a systematic selection of markets (identifying priority countries/bodies) and prepare to implement the aforementioned strategy. Saastamoinen et al. (2020) and Reijonen et al. (2016) have already shown that the level of SME participation in public tenders is linked to how entrepreneurial their approach is, i.e. how actively they perform in the initial search and presentation phases of the process. According to Clear et al. (2020), SMEs need two different strategies and mindsets to find and win CBPP contracts: commitment to the international market; and openness to working in networks.

One interesting conclusion that emerged from the literature review and the content of the interviews is that companies regularly attend forums, gatherings, conferences and seminars in search of knowledge to improve their management or a specific project, but these face-to-face events, which are considered more fruitful than those currently provided by social networks, are also a chance to meet interesting prospects. The key is to make that networking truly effective by turning it into a crucial strategy, establishing relationships based on not only the one-off interest of the moment but also establishing a network of long-term contacts. Recently, Herz and Varela-Irima (2020) showed that the key to success are these links established between public officials and companies, either over time or through their personal relationships, while Uyarra et al. (2019) and Saastamoinen et al. (2020) suggest that a more organised dialogue is necessary between suppliers and contracting authorities.

In short, the results of this research suggest that networking, procurement 4.0 and a strategic international marketing approach are the main factors that serve as catalysts for the future increase of SME participation in the cross-border procurement market. Therefore, future academic studies with mixed research methods that consider these variables together are required. Additionally, despite not being the aim of this research, more recent literature (e.g. Rosell, 2021) encourages us to consider the important role that variables related with Green Public Procurement will play.

Moreover, implications also arise for the administration. We agree with Arend (2014) that policymakers must help SMEs, and especially the smallest ones, to build dynamic capabilities; the proposals linked to networking described by these authors include benchmarking "and other activities and resources that could encourage planning and improvements in operational change processes. Policymakers could also promote the DC-type skills by requiring them". Also, in the case of countries with large numbers of small companies, the administration should first identify which companies employ the approach proposed previously, and which ones really have the potential to operate directly in the cross-border public procurement market, and encourage them to present bids as part of a group with other companies and collaborators, encouraging the concept of "supplier development", and especially, as indicated by Raijonen et al., (2022), when they are large tenders. This should be complemented with actions aimed at increasing their knowledge of procedures and 
requirements, without forgetting the development of specific skills with the SMEs themselves through mentoring programmes.

Our study also had limitations which unveil potential future areas of research., Given the qualitative and exploratory nature of this study, and despite the fact that Loader (2013) indicated that companies report the same barriers when competing for public contracts irrespective of jurisdiction, we believe that when cross-border public contracts are analysed specifically, research needs to go one step further and could be complemented by increasing the number of countries studied, broken down by sectors and tendering bodies, and making the research longitudinal, as our study clearly shows that SMEs believe that each country and/or funding or local body, and at every point in time, poses different challenges, thus revealing the different characteristics of each bid.

Despite the contributions made in this initial analysis of the CBPP market from the perspective of networking in the field of Spanish SMEs, the results obtained may not be generally applicable to all sectors/markets and types of SMEs. Not only was this not the objective of the research methodology used, but also, as highlighted by Frank and Roessl (2015), SMEs are extremely diverse and it is not always possible to draw conclusions that can be applied to all of them. Furthermore, Clear et al., (2020) recently stated that compared to large EU countries, smaller ones are more likely to award contracts to firms from other countries. This points to the need for more theory-based studies, closing the gap between existing research and cross-border public procurement practices. Although an attempt was made to reduce the inevitable subjectivity of the researcher in the coding of dynamic capabilities-by having different researchers compare them and discuss the classification of evidence-until the contributions of future studies in this under-researched area are consolidated, it would be unwise to make generalisations about all the results obtained. Nevertheless, this paper contributes to the literature by starting a dialogue between the literature on the dynamic capabilities of internationalisation, networking and the role of SMEs in the cross-border public procurement market.

Funding Open Access funding provided thanks to the CRUE-CSIC agreement with Springer Nature. This research has been developed within the framework of the Funding for Consolidated Research teams of the Regional Council of Innovation, Universities, Science and Digital Society (AICO2021/144/GVA) and the Funding for Special Research Actions of Universitat de València (UV-INV-AE-1553911), and the Spanish Research Agency. Ministry of Economy, Industry and Competitiveness's R\&D Program (Project ECO2017-83051-R).

Open Access This article is licensed under a Creative Commons Attribution 4.0 International License, which permits use, sharing, adaptation, distribution and reproduction in any medium or format, as long as you give appropriate credit to the original author(s) and the source, provide a link to the Creative Commons licence, and indicate if changes were made. The images or other third party material in this article are included in the article's Creative Commons licence, unless indicated otherwise in a credit line to the material. If material is not included in the article's Creative Commons licence and your intended use is not permitted by statutory regulation or exceeds the permitted use, you will need to obtain permission directly from the copyright holder. To view a copy of this licence, visit http://creativecommons.org/licen ses/by/4.0/. 


\section{References}

Albano GL, Antellini Russo F, Castaldi G, Zampino R (2015) Evaluating small businesses' performance in public e-procurement: evidence from the Italian government's e-marketplace. J Small Bus Manag 53:229-250. https://doi.org/10.1111/jsbm.12190

Arend RJ (2014) Entrepreneurship and dynamic capabilities: how firm age and size affect the "capability enhancement-SME performance' relationship. Small Bus Econ 42:133-157. https://doi.org/10. 1007/s11187-012-9461-9

Augier M, Teece DJ (2007) Dynamic capabilities and multinational enterprise: Penrosean insights and omissions. Manag Int Rev 47(2):175-192

Blyler M, Coff RW (2003) Dynamic capabilities, social capital, and rent appropriation: Ties that split pies. Strateg Manag J 24(7):677-686

Cabras I (2011) Mapping the spatial patterns of public procurement: a case study from a peripheral local authority in Northern England. Int J Publi Sect Manag 24(3):187-205

Calderón García H, Fayos Gardó T, García García JM (2018) SMEs' dynamic learning capabilities in international public procurement. J Mod Proj Manag 5(3):14-23

Chibani A, Delorme X, Dolgui A, Pierreval H (2018) Dynamic optimisation for highly agile supply chains in e-procurement context. Int J Prod Res 56(17):5904-5929. https://doi.org/10.1080/00207 543.2018.1458164

Ciravegna L, Majano SB, Zhan G (2014) The inception of internationalization of small and medium enterprises: The role of activeness and networks. J Bus Res 67(6):1081-1089. https://doi.org/10. 1016/j.jbusres.2013.06.002

Clear S, Clifford G, Cahill D, Allen B (2020) A new methodology for improving penetration, opportunity-visibility and decision-making by SMEs in EU public procurement. Eur Procurement \& Pub Private Partnership L Rev 15:83-107

Dirección General de Industria y de la Pequeña y Mediana Empresa (2020) Retrato de la PYME DIRCE a 1 de enero de 2019. http://www.ipyme.org/Publicaciones/Retrato-PYME-DIRCE-1-enero-2019.pdf. Accessed 24 Feb 2022

de Bas P, Hausemer P, Kruger T, Rabuel L, de Vet JM, Vincze M (2020) Analysis of the SMEs' participation in public procurement and the measures to support it - 697/PP/GRO/IMA/18/1131/10226. In: Final Report, Directorate-General for Internal Market, Industry, Entrepreneurship and SMEs, European Commission. https://data.europa.eu/doi/. https://doi.org/10.2873/417621

Duarte M, Davies G (2003) Testing the conflict-performance assumption in business-to-business relationships. Ind Mark Manag 32(2):91-99. https://doi.org/10.1016/S0019-8501(02)00223-7

Eisenhardt KM (1989) Building theories from case study research». Acad Manag Rev 14(4):532-550

Eisenhardt KM, Graebner ME (2007) Theory building from cases: opportunities and challenges. Acad Manage J 50(1):25-32. https://doi.org/10.5465/amj.2007.24160888

Ellis PD (2011) Social ties and international entrepreneurship: Opportunities and constraints affecting firm internationalization. J Int Bus Stud 42(1):99-127. https://doi.org/10.1057/jibs.2010.20

Ellis P, Pecotich A (2001) Social factors influencing export initiation in small and medium-sized enterprises. J Mark Res 38(1):119-130. https://doi.org/10.1509/jmkr.38.1.119.18825

Eriksson T (2014) Processes, antecedents and outcomes of dynamic capabilities. Scand J Manag 30(1):65-82. https://doi.org/10.1016/j.scaman.2013.05.001

European Commission (2017) Public procurement. http://ec.europa.eu/trade/policy/accessing-markets/ public-procurement/. Accesed 18 November 2019

Fang EE, Zou S (2009) Antecedents and consequences of marketing dynamic capabilities in international joint ventures. J Int Bus Stud 40(5):742-761. https://doi.org/10.1057/jibs.2008.96

Felin T, Powell TC (2016) Designing organizations for dynamic capabilities. Calif Manage Rev 58(4):7896. https://doi.org/10.1525/cmr.2016.58.4.78

Fernhaber SA, Li D (2013) International exposure through network relationships: implications for new venture internationalization. J Bus Ventur 28(2):316-334. https://doi.org/10.1016/j.jbusvent.2012.05.002

Flynn A, Davis P, McKevitt D, McEvoy E (2013) Mapping public procurement in Ireland. Public Procurement Law Review 74-95. http://orca.cf.ac.uk/94461/

Flynn A (2017) Re-thinking SME disadvantage in public procurement. J Small Bus Enterp Dev 24(4):991-1008. https://doi.org/10.1108/JSBED-03-2017-0114

Flynn A (2018) Investigating the implementation of SME-friendly policy in public procurement. Policy Studies 39(4):422-443. https://doi.org/10.1080/01442872.2018.1478406 
Flynn A, Davis P (2016) Firms' experience of SME-friendly policy and their participation and success in public procurement. J Small Bus Enterp Dev 23(3):616-635. https://doi.org/10.1108/ JSBED-10-2015-0140

Flynn A, Davis P (2017) Explaining SME participation and success in public procurement using a capability-based model of tendering. J Public Procure 17(3):337-372. https://doi.org/10.1108/ JOPP-17-03-2017-B003

Flynn A, Davis P (2017) Investigating the effect of tendering capabilities on SME activity and performance in public contract competitions. Int Small Bus J 35(4):449-469. https://doi.org/10.1177/ 0266242616630035

Frank H, Roessl D (2015) Problematization and conceptualization of "entrepreneurial SME Management" as a field of research: overcoming the size-based approach. RMS 9(2):225-240. https:// doi.org/10.1007/s11846-014-0154-4

Frasquet M, Dawson J, Mollá A (2013) Post-entry internationalisation activity of retailers. Manag Decis 51(7):1510-1527. https://doi.org/10.1108/MD-02-2013-0081

Frasquet M, Dawson J, Calderón H, Fayos T (2018) Integrating embeddedness with dynamic capabilities in the internationalisation of fashion retailers. Int Bus Rev 27(4):904-914. https://doi.org/10. 1016/j.ibusrev.2018.02.002

Gilmore A (2011) Entrepreneurial and SME marketing. J Res Mark Entrep 13(2):137-145. https://doi. org/10.1108/14715201111176426

Gilmore A, Carson D, Rocks S (2006) Networking in SMEs: Evaluating its contribution to marketing activity. Int Bus Rev 15(3):278-293. https://doi.org/10.1016/j.ibusrev.2006.02.003

Glas AH, Eßig M (2018) Factors that influence the success of small and medium-sized suppliers in public procurement: evidence from a centralized agency in Germany. Supply Chain Manag 23(1):65-78. https://doi.org/10.1108/SCM-09-2016-0334

Hafsa F, Darnall N, Bretschneider S (2021) Estimating the true size of public procurement to assess sustainability impact. Sustainability 13(3):1448. https://doi.org/10.3390/su13031448

Hanna V, Walsh K (2008) Interfirm cooperation among small manufacturing firms. Int Small Bus J 26(3):299-321. https://doi.org/10.1177/0266242608088740

Herz B, Varela-Irimia XL (2020) Border effects in European public procurement. J Econ Geogr 20(6):1359-1405. https://doi.org/10.1093/jeg/lbaa001

Huberman AM, Miles M, Saldana J (2014) Qualitative data analysis: A methods sourcebook, 3rd edn. Los Angeles, London, New Delhi, Singapore, Washington DC, SAGE Publications

Jack SL, Anderson AR, Drakopoulou Dodd S (2015) Using the constant comparative Technique to consider network change and evolution. In: Neergaard H, Leitch CM (eds) Handbook of Qualitative Research Techniques and Analysis in Entrepreneurship. Edward Elgar Publishing, Cheltenham, pp 21-51

Karjalainen K, Kemppainen K (2008) The involvement of small-and medium-sized enterprises in public procurement: Impact of resource perceptions, electronic systems and enterprise size. J Purch Supply Manag 14(4):230-240. https://doi.org/10.1016/j.pursup.2008.08.003

Knight GA, Cavusgil ST (2004) Innovation, organizational capabilities, and the born-global firm. J Int Bus Stud 35(2):124-141. https://doi.org/10.1057/palgrave.jibs.8400071

Kutlina-Dimitrova Z, Lakatos C (2016) Determinants of direct cross-border public procurement in EU Member States. Rev World Econ 152(3):501-528. https://doi.org/10.1007/s10290-016-0251-3

Larson A (1992) Network dyads in entrepreneurial settings: A study of the governance of exchange relationships. Adm Sci Q 37(1):76-104. https://doi.org/10.2307/2393534

Leppäaho T, Chetty S, Dimitratos P (2018) Network embeddedness in the internationalization of biotechnology entrepreneurs. Entrep Reg Dev 30(5-6):562-584. https://doi.org/10.1080/08985626. 2017.1408697

LICIRED (2021) Empresas españolas ganan 1.900 licitaciones en América latina por valor de casi 2.000 millones.https://licired.eu/empresas-espanolas-ganan-1-900-licitaciones-en-america-latinapor-valor-de-casi-2-000-millones/. Accessed 14 November 2021

Liesch PW, Welch LS, Welch D, McGaughey SL, Petersen B, Lamb P (2002) Evolving strands of research on firm internationalization: an Australian-Nordic perspective. Int Stud Manag Organ 32(1):16-35. https://doi.org/10.1080/00208825.2002.11043652

Loader K (2005) Supporting SMEs through government purchasing activity. Int J Entrep Innov 6(1):17-26. https://doi.org/10.5367/0000000053026383

Loader K (2013) Is public procurement a successful small business support policy? A review of the evidence. Eviron Plann C Gov Policy 31(1):39-55. https://doi.org/10.1068/c1213b 
Loader K (2015) SME suppliers and the challenge of public procurement: Evidence revealed by a UK government online feedback facility. J Purch Supply Manag 21(2):103-112. https://doi.org/10. 1016/j.pursup.2014.12.003

Loader K (2018) Small-and medium-sized enterprises and public procurement: a review of the UK coalition government's policies and their impact. Environment and Planning c: Politics and Space 36(1):47-66. https://doi.org/10.1177/2399654417692987

Loosemore M, Alkilani SZ, Murphy R (2021) The institutional drivers of social procurement implementation in Australian construction projects. Int J Proj Manag 39(7):750-761. https://doi.org/ 10.1016/j.ijproman.2021.07.002

Magina P (2020) The OECD’s work on Public Procurement: Resahping the global agenda. In: Castelli A, Piga G, Saussier S, Tátrai T (Eds.). The Challenges of Public Procurement Reforms. Routledge, pp xv-xvii

Masiello B, Izzo F, Canoro C (2013) The structural, relational and cognitive configuration of innovation networks between SMEs and public research organisations. Int Small Bus J 33(2):169-193. https:// doi.org/10.1177/0266242613485610

McGrath H, Medlin CJ, O'Toole T (2019) A process-based model of network capability development by a start-up firm. Ind Mark Manag 80:214-227. https://doi.org/10.1016/j.indmarman.2017.11.011

Mckevitt D, Davis P (2013) Microenterprises: how they interact with public procurement processes. Int J Public Sect Manag 26(6):469-480. https://doi.org/10.1108/IJPSM-06-2012-0086

Mitrega M, Forkmann S, Ramos C, Henneberg SC (2012) Networking capability in business relationships—concept and scale development. Ind Mark Manag 41(5):739-751. https://doi.org/10.1016/j. indmarman.2012.06.002

Morgan NA, Feng H, Whitler KA (2018) Marketing Capabilities in International Marketing. J Int Mark 26(1):61-95. https://doi.org/10.1509/jim.17.0056

Morrissey B, Pittaway L (2004) A study of procurement behaviour in small firms. J Small Bus Enterp Dev 11(2):254-262. https://doi.org/10.1108/14626000410537191

Mu J (2014) Networking capability, network structure, and new product development performance. IEEE Trans Eng Manage 61(4):599-609. https://doi.org/10.1109/TEM.2014.2359160

Muñoz-Garcia C, Vila J (2019) Value creation in the international public procurement market: In search of springbok firms. J Bus Res. 101:516-521. https://doi.org/10.1016/j.jbusres.2018.12.041

Muro JF (2012) La internacionalización multilateral (1. ${ }^{a}$ ed.). Manuales ICEXCECO, Madrid. https:// www.icex.es/icex/es/Navegacion-zona-contacto/libreria-icex/PUB2019817295.html?idTema= 10707000\&idColeccion=12060362. Accessed 14 November 2021

Namagembe S, Mpeera JN, Kalid A (2021) An examination of SME involvement in public procurement under bid lot sizing. J Public Procure 21(4):370-398. https://doi.org/10.1108/JOPP-04-2020-0031

Nerkar A, Paruchuri S (2005) Evolution of R\&D capabilities: the role of knowledge networks within a firm. Manage Sci 51(5):771-785. https://doi.org/10.1287/mnsc.1040.0354

Nieves J (2014) Social relationships, dynamic capacities and innovation: an empirical analysis of the hotel industry. Revista Europea De Dirección y Economía De La Empresa 23(4):166-174. https:// doi.org/10.1016/j.redee.2014.09.002

Nordquist M, Hall A, Melin L (2009) Qualitative research on family businesses: the relevance and usefulness of the interpretative approach. J Manag Organ 15(3):294-308. https://doi.org/10.5172/jmo. 2009.15.3.294

Obwegeser N, Müller SD (2018) Innovation and public procurement: terminology, concepts, and applications. Technovation 74:1-17. https://doi.org/10.1016/j.technovation.2018.02.015

OECD (2019) Government at a Glance 2019. OECD Publishing, Paris. https://doi.org/10.1787/8ccf5 c38-en

Patton MQ (2002) Two decades of developments in qualitative inquiry: A personal, experiential perspective. Qual Soc Work 1(3):261-283. https://doi.org/10.1177/1473325002001003636

Peck F, Cabras I (2010) The Impact of Local Authority Procurement on Local Economies The Case of Cumbria North West England. Public Policy and Administration 26(3):307-331. https://doi.org/10. $1177 / 0952076709356859$

Pehrsson T, Ghannad N, Pehrsson A, Abt T, Chen S, Erath F, Hammarstig T (2015) Dynamic capabilities and performance in foreign markets: developments within international new ventures. J Int Entrep 13(1):28-48. https://doi.org/10.1007/s10843-014-0139-z

Pinho JC, Prange C (2016) The effect of social networks and dynamic internationalization capabilities on international performance. J World Bus 51(3):391-403. https://doi.org/10.1016/j.jwb.2015.08.001

Pitelis CN, Teece DJ (2010) Cross-border market co-creation, dynamic capabilities and the entrepreneurial theory of the multinational enterprise. Ind Corp Chang 9(4):1247-1270. https://doi.org/10.1093/icc/dtq030 
Pratt MG (2009) From the editors: For the lack of a boilerplate: tips on writing up (and reviewing) qualitative research. Acad Manage J 52(5):856-862. https://doi.org/10.5465/amj.2009.44632557

Luo Y (2002) Contract, cooperation, and performance in international joint ventures. Strategic Manag J 23(10):903-919.https://doi.org/10.1002/smj.261

Quayle M (2002) Purchasing in small firms. Eur J Purchasing Supply Manage 8(3):151-159. https://doi. org/10.1016/S0969-7012(02)00005-9

Reijonen H, Tammi T, Saastamoinen J (2016) SMEs and public sector procurement: Does entrepreneurial orientation make a difference? Int Small Bus J 34(4):468-486. https://doi.org/10.1177/0266242614556661

Reijonen H, Saastamoinen J, Tammi T (2022) The importance of SMEs' network partners in consortium bidding for public sector tenders. Int J Publi Sect Manag 35(1):1-15. https://doi.org/10.1108/ IJPSM-04-2021-0082

Rosell J (2021) Getting the green light on green public procurement: macro and meso determinants. J Clean Prod 279. https://doi.org/10.1016/j.jclepro.2020.123710

Saastamoinen J, Reijonen H, Tammi T (2017) The role of training in dismantling barriers to SME participation in public procurement. J Public Procure 17(1):1-30. https://doi.org/10.1108/ JOPP-17-01-2017-B001

Saastamoinen J, Reijonen H, Tammi T (2020) SMEs' market orientation toward public sector customers in public procurement. Int J Publi Sect Manag 34(1):1-16. https://doi.org/10.1108/IJPSM-05-2020-0131

Saastamoinen J, Tammi T, Reijonen H (2018) E-procurement and SME involvement in public procurement of innovations: An exploratory study. Int J Procure Manag 11(4):420-442. https://www.inder scienceonline.com/doi/pdf/https://doi.org/10.1504/IJPM.2018.092768

Schapper PR, Veiga Malta JN, Gilbert DL (2006) An analytical framework for the management and reform of public procurement. J Public Procure 6(1/2):1-26. https://doi.org/10.1108/ JOPP-06-01-02-2006-B001

Secretaría de Estado de Comercio (2021) Plan de Acción para la Internacionalización de la Economía Española 2021-2022. https://comercio.gob.es/es-es/estrategia_internacionalizacion/Documents/ Plan_Accion_Intern_Economia_Espanola_21-22.pdf. Accessed 24 February 2022

Selnes F, Sallis J (2003) Promoting relationship learning. J Mark 67(3):80-95. https://doi.org/10.1509/ jmkg.67.3.80.18656

Sinkovics RR, Alfoldi EA (2012) Progressive focusing and trustworthiness in qualitative research. Manag Int Rev 52(6):817-845. https://doi.org/10.1007/s11575-012-0140-5

Soylu A, Corcho O, Elvesæter B, Badenes-Olmedo C, Blount T, Martínez FY et al (2022) TheyBuyForYou platform and knowledge graph: Expanding horizons in public procurement with open linked data. Semantic Web 13(2):265-291. https://doi.org/10.3233/SW-210442

Stritch JM, Bretschneider S, Hsueh L (2018) Value complexity, structure, and technology in public procurement process performance. In: Academy of Management Proceedings 2018(1):12639. Briarcliff Manor, NY 10510: Acad Manage. https://doi.org/10.5465/AMBPP.2018.120

Tammi T, Reijonen H, Saastamoinen J (2016) Are entrepreneurial and market orientations of small and medium-sized enterprises associated with targeting different tiers of public procurement? Eviron Plann C Gov Policy 35(3):457-475. https://doi.org/10.1177/0263774X16666814

Uyarra E, Ribeiro B, Dale-Clough L (2019) Exploring the normative turn in regional innovation policy: responsibility and the quest for public value. Eur Plan Stu 27(12):2359-2375. https://doi.org/10. 1080/09654313.2019.1609425

Weerawardena J, Mort GS, Liesch PW, Knight G (2007) Conceptualizing accelerated internationalization in the born global firm: a dynamic capabilities perspective. J World Bus 42(3):294-306. https://doi. org/10.1016/j.jwb.2007.04.004

World Bank Group (2016) Benchmarking public procurement. Assessing public procurement regulatory systems in 180 economies. https://documents1.worldbank.org/curated/en/121001523554026106/ Benchmarking-Public-Procurement-2017-Assessing-Public-Procurement-Regulatory-Systems-in180-Economies.pdf. Accessed 24 February 2022

Yin RK (2014) Case study research: design and methods. Sage, Thousand Oaks

Yin RK (2003) Designing case studies. Qual Res Methods 5(14):359-386

Publisher's note Springer Nature remains neutral with regard to jurisdictional claims in published maps and institutional affiliations. 